\title{
Morphotectonic Evidences for Strike-Slip Component of the Reverse Fault at the Southeastern Plunge of Bashiqa Anticline
}

\author{
Alaa N. Hamdon \\ Remote Sensing Center \\ University of Mosul
}

(Received 17/6/2019 , Accepted 28/11/2019)

\begin{abstract}
Sedimentary rock beds and drainage pattern offset took place predominantly at the southeastern plunge of Bashiqa anticline which indicates shear zone in this area represented by apparent left-lateral fault separation of reverse fault dipping to the southeast. This study will discuss and update the geological information of the impressions of the fault on the surface topography based on the morphotectonic evidences including visual interpretation of the satellite image for the landforms and regional stress analysis of the study area. The variations of landform features are regarded as an efficient geological indicator for tectonic activity in the area.

Keywords: Bashiqa, Strike-slip, Fault, Anticline.
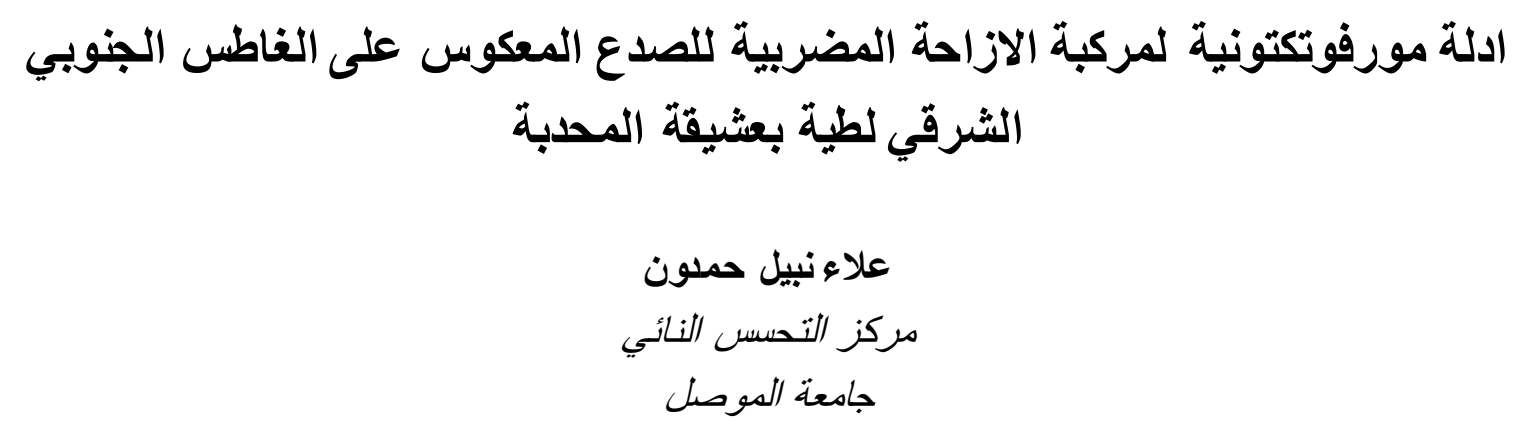

\section{الملخص}

ان وجود الازاحة الافقية للطبقات الرسوبية وانماط الصريف المائي والتشوه المورفولوجي على الغاطس الجنوبي الشرقي من طية بعشيقة المحبة تثير الى وجود نطاق جهد قصي في تلك المنطقة، وان من اهم المظاهر المورفوتكتونية المتكونة نتيجة هذا الجها القصي هو ازاحة مضربية لصدع معكوس مائل نحو الجنوب الثرقي. لذلك ارتأت هذه الدراسة الى تحديث المعلومات الجيولوجية لهذا الصدع بالاعتماد على الهيه الأدلة المورفوتكتونية التي تم تحيدها من خلال التفسير البصري والمكاني لمرئية فضائية من اجل تطيل الاشكال الارضية والجها العام المكون للطي في شمالي العراق وتلك المنطقة. ان تحديد هذا الصدع ذي الازاحة المضربية
\end{abstract}




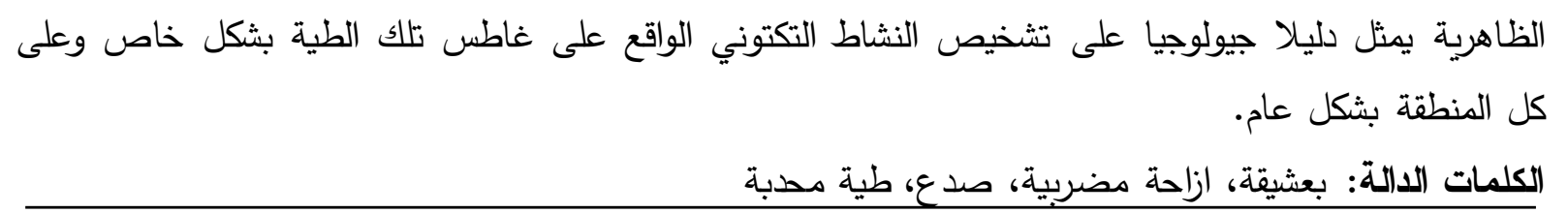

\section{INTRODUCTION}

Studying the drainage pattern and landscapes deformation alongside the faults presents crucial insights onto fault deformation and recent day tectonic activity, and that could be related to the strike-slip movement along those faults (Khalifa et. al., 2018).

This study aims to illustrate a new morphotectonic evidence for the existing fault at the southeastern plunge of Bashiqa anticline, which has been studied previously and characterized as a thrust fault dipping towards the southeast. Besides, the goal of this study is to update the geometrical displacement of the same fault following the new morphotectonic evidences.

The studied area is located in Northern Iraq, within Nineveh Governorate (Fig.1), close to Bashiqa town and at geographical coordinates $\left(36^{\circ} 27^{\prime} 41^{\prime \prime} \mathrm{N}\right.$ and $43^{\circ} 24^{\prime} 23^{\prime \prime}$ E).

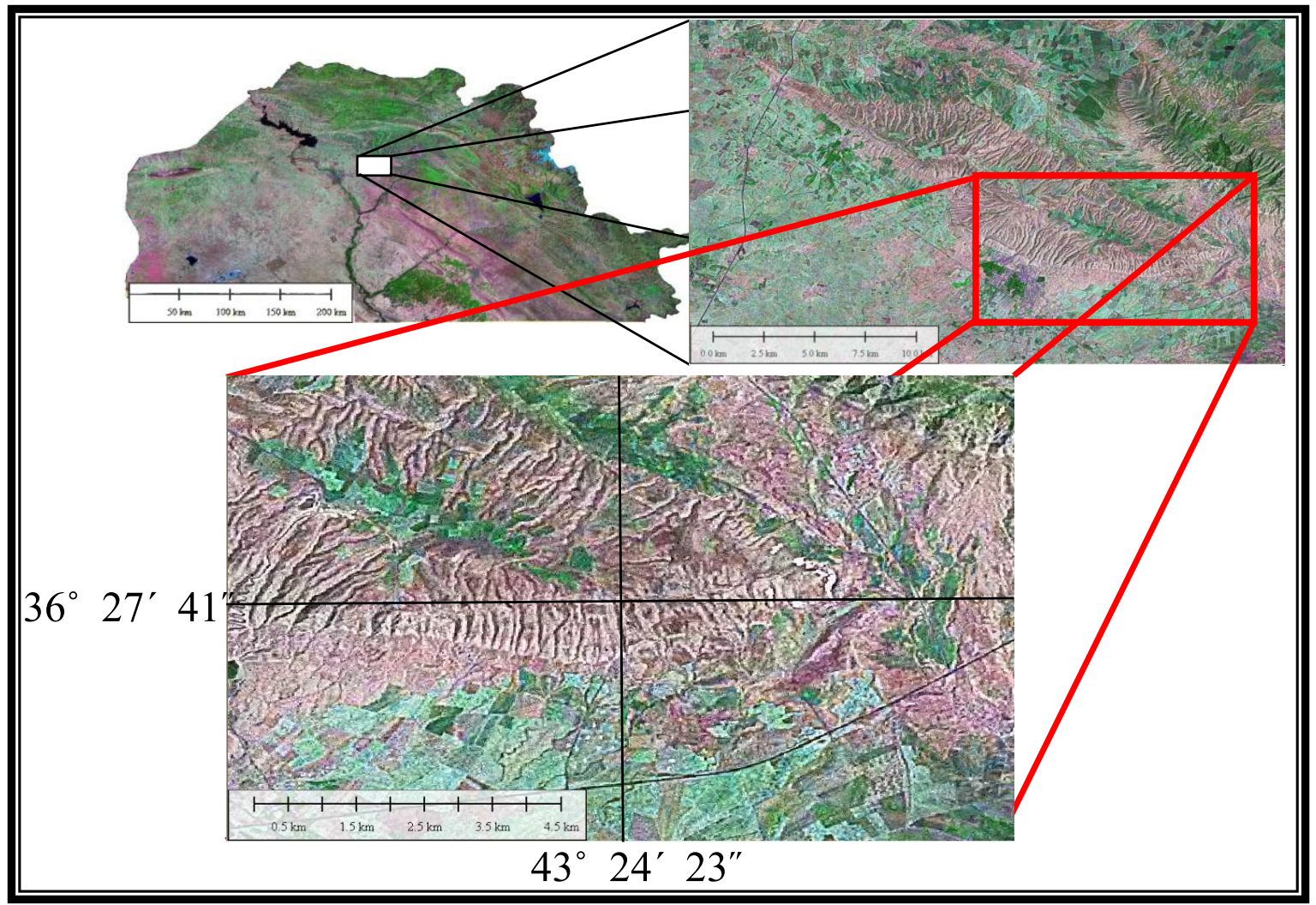

Fig. 1: Geographic site of the study area 


\section{GEOLOGICAL SETTING}

The research area is located at the Foot Hill Zone within Chumchemal- Butmah subzone (Mosul high) (Jassim and Goff, 2006). Tectonically, this zone is considered a relatively semi-active zone, and many kinds of literature refer to the presence of faults in this zone, either dip-slip or strike-slip faults (Fig.2).

The main geological structures in the research location are Bashiqa anticline and reverse-fault, and the anticline is an asymmetric fold towards the southwest, while the faults are cutting the anticline axis transversely or parallel to it (Salih and AlDaghastani,1993; Al-azzawi, 2010). Also, some other geological structures exist in the anticline such as joints and fractures, in addition to some geomorphologic features such as iron flat topography at both limbs of the anticline.

The lithology of the study area consists of the limestone beds mainly belong to the Pila Spi Formation (upper-middle Eocene), forming the skeletal body of Bashiqa anticline; these beds are overlain by Fat'ha Formation (lower-middle Miocene) of different lithological beds (gypsum, limestone, marl, claystone and siltstone).

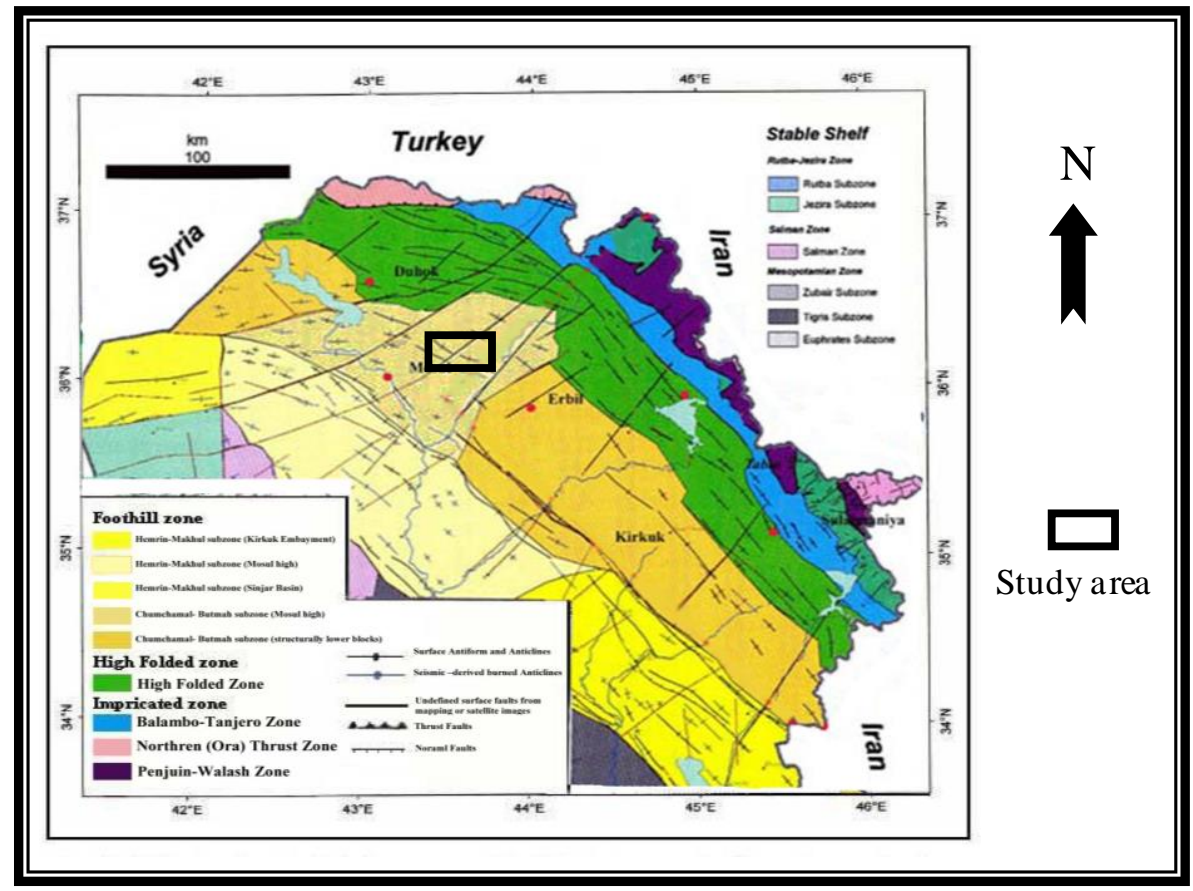

Fig.2: Tectonic map of Northern parts of Iraq (Jassim and Goff, 2006).

The exposures of this formation as well as the overlying Injana terrestrial Formation (Upper Miocene) are distributed as outer structural ridges at the limbs of the Bashiqa anticline (Fig.3). 


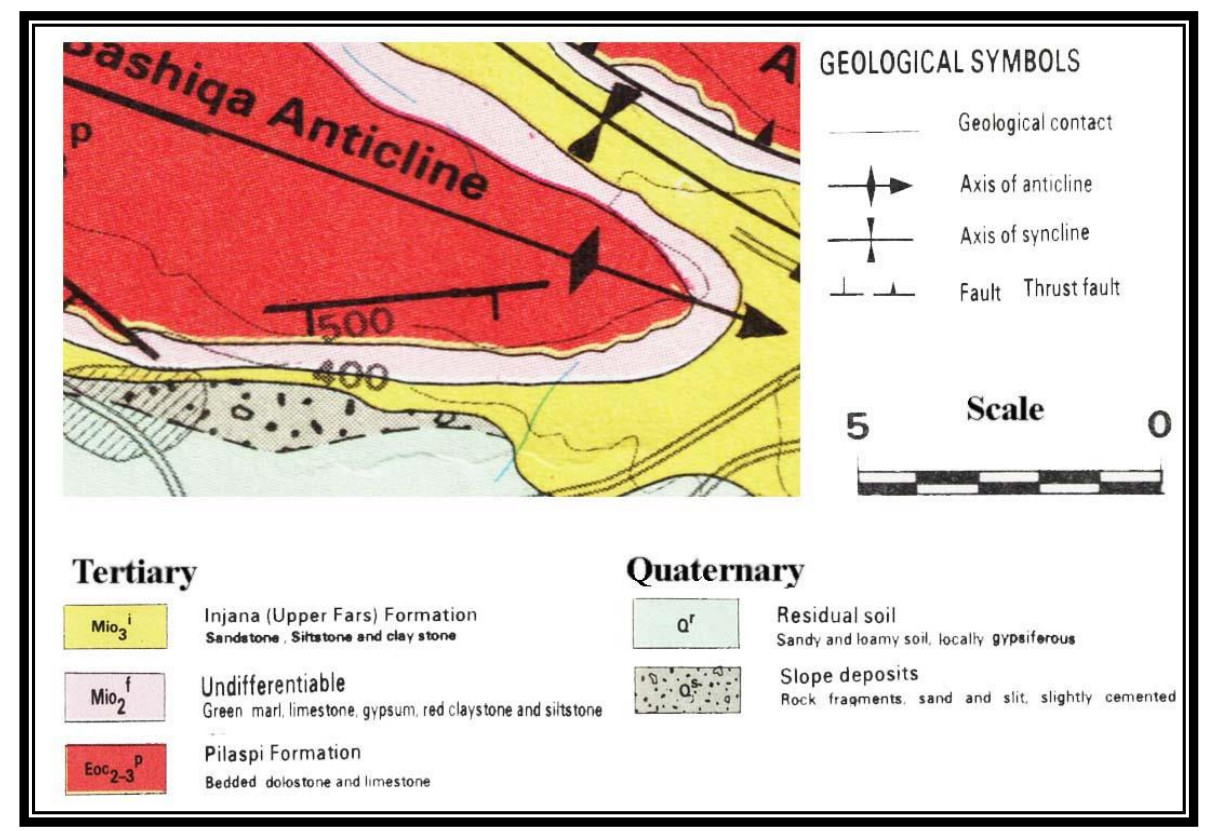

Fig. 3: Geologic map of the research area (GEOSURV, 1995)

\section{GEOMORPHOLOGIC LANDFORMOFFSET}

The fault in the study area is marked as a topographic feature cutting obliquely the plunge of Bashiqa anticline. A strike-slip movement has been recognized at the northern structural ridges and southern structural ridges of the Pila Spi Formation. The displacement has been determined through the visual interpretation of satellite images for the study area (Fig. 4A,4C). This topographic deformation is an output of the apparent strike-slip faulting of the intended fracture regarding to the anticline shape.

The strike-slip movement produced a curved plunge (southeastern plunge) of Bashiqa anticline and initiated a modified propagation direction.

This fault is oblique relative to Bashiqa anticline axis, which is in a close match with the direction of the regional stress in the area, and this is considered as practical evidence to prove the hypothesis of the oblique-slip fault (strike- and dip-slip) more than the hypothesis of dip-slip fault which has been determined by previous studies.

\section{DRAINAGE PATTERN RESPONSE}

The change of drainage systems as a response to the deformation of geologic structures provides essential criteria to the tectonic setting presently in any area and to the morphotectonic modification that has existed (Killer and Pinter, 2002). In the study area, the response of a drainage network has been developed during the evolution of the strike-slip fault; moreover, the growth and propagation of Bashiqa anticline in the new tectonic setting. According to (Salih and Al-Daghastani,1993), this fault has a thrusting attitude toward the northwest. This movement could be combined with a strike-slip movement to produce a net-slip displacement marked by the deformation of the drainage network; overprinting the previous drainage. A morphotectonic analysis and a visual interpretation have been made on the drainage pattern to understand the development of the apparent strike-slip separation of the reverse fault in the area and 
to deduce the major geologic features that currently control the drainage deformation (the fault or the anticline propagation). The displacement in the drainage pattern is considered as a geomorphic index for the oblique-slip to strike-slip fault displacement (Goldsworthy and Jackson, 2000) (Fig.4b, 4D).

The visual interpretation shows reactivation of the fault reverse slip as apparent left-lateral strike-slip displacement at the southeastern plunge of Bashiqa anticline upon the displacement in the drainage pattern and sudden modification in the flow direction. The synchronous growth of the anticline with the evolution of the fault raised the southern parts of the fault region, besides the oblique relationship between the axis of the anticline and the fault plane which has shaped the drainage network in this way.

\section{TOPOGRAPHY DEFORMATION}

A magnificent relation between the land surface and active tectonic represented by the geologic and geomorphologic set-up (Arzhannikova, et al., 2011), and that can be noticed at the southeastern plunge of Bashqia anticline, specifically at the southern part of the fault-trace where there is a noticeable uplift and shift toward the northeast as compared with the northern part of the fault-trace and that would be referred to an oblique-slip movement (Fig.5). 


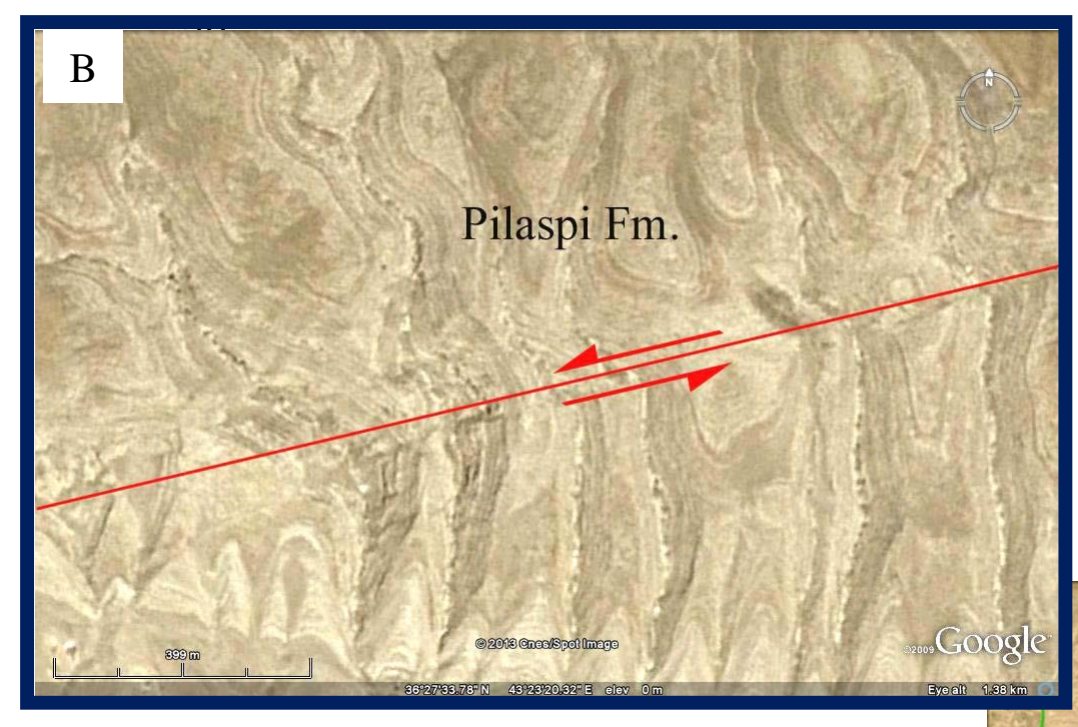

Alaa N. Hamdon
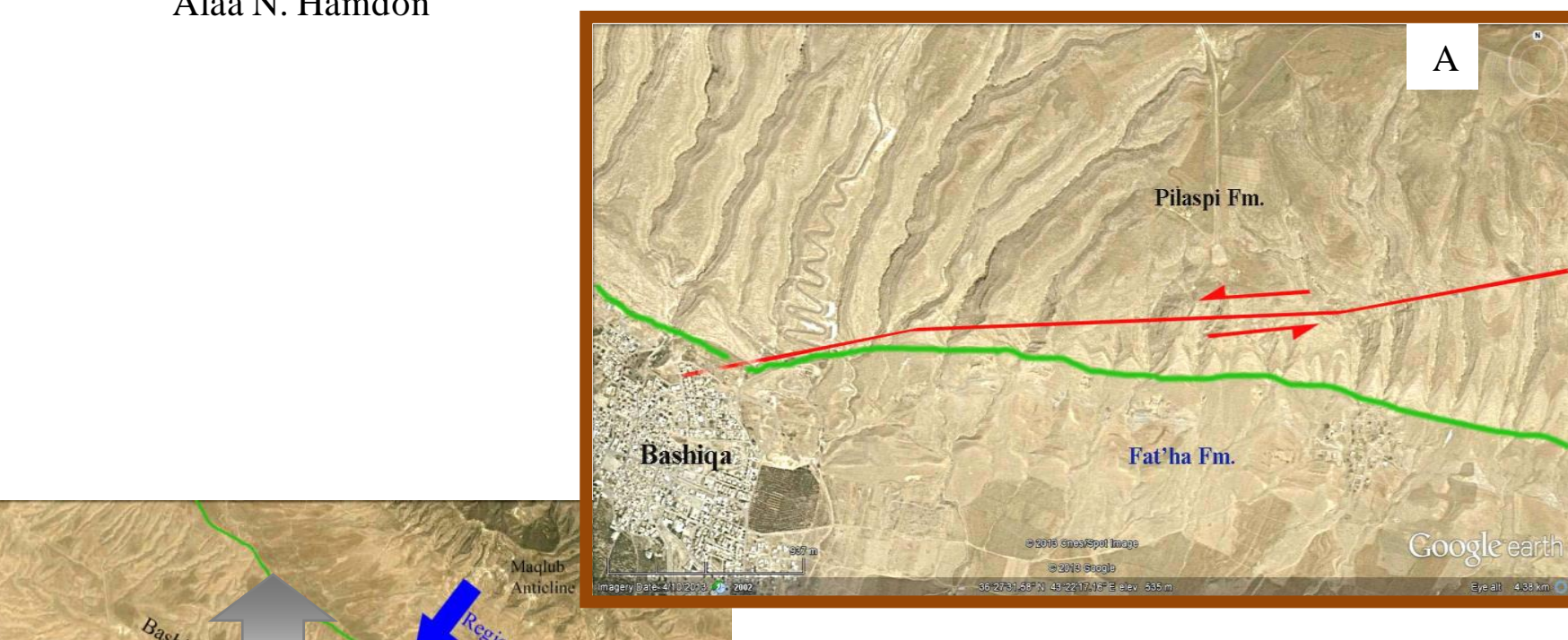

D. $\mathrm{A} \quad \mathrm{B}$
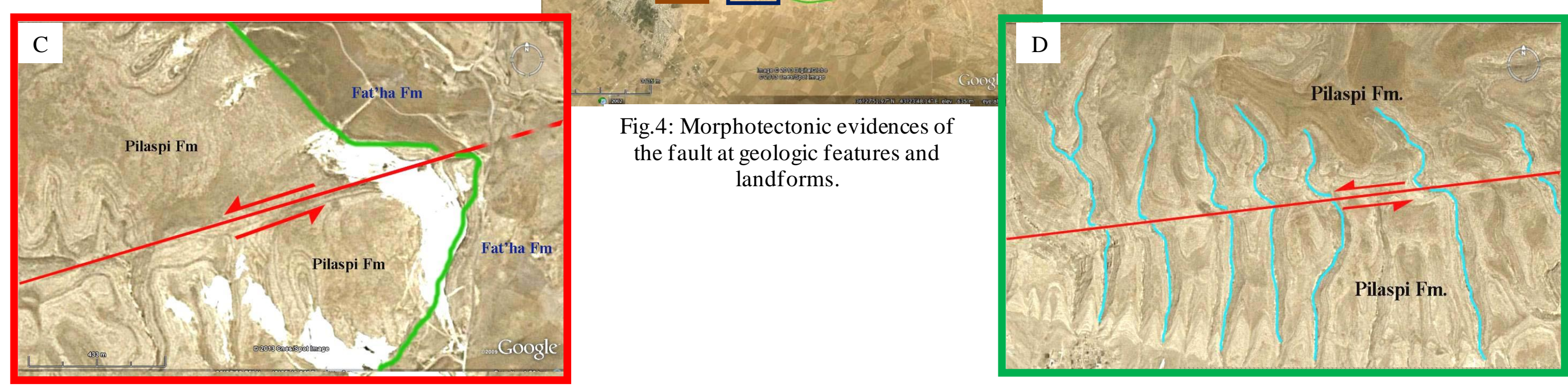

Fig.4: Morphotectonic evidences of the fault at geologic features and landforms.

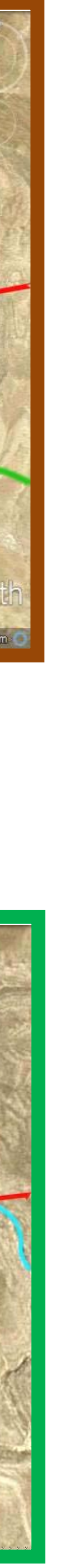


The morphological-feature of Bashiqa anticline was deformed at its southeastern plunge, and the deformation is very clear through a linear deformation and that would be referred to as a fault that deformed the anticline's plunge linearly with horizontal displacement (Fig.5).

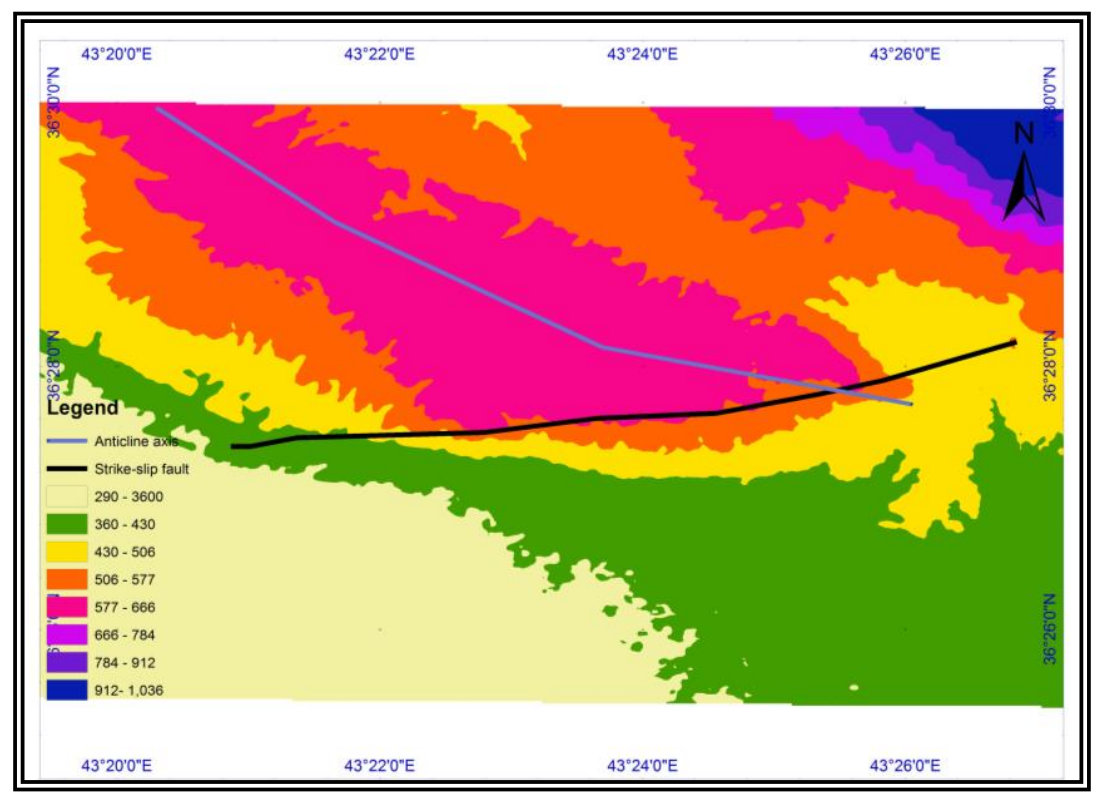

Fig.5: The fault impact on the anticline's morphology and the topography in digital elevation map

Also, the drainage pattern shows severe incision proposing a recent uplift by the activity of the fault (Moriyama and Lin, 2002). The complex drainage pattern of the southern limb of the anticline at its southeastern plunge is the output of streams shifting or abandoning outlets as they cross the faulting-zone along which there is apparent strike-slip faulting. The effect of apparent strike-slip movement of the fault is detectable in the drainage stream shape and the deformation of the topography at the southeastern plunge of the anticline (Fig.6).

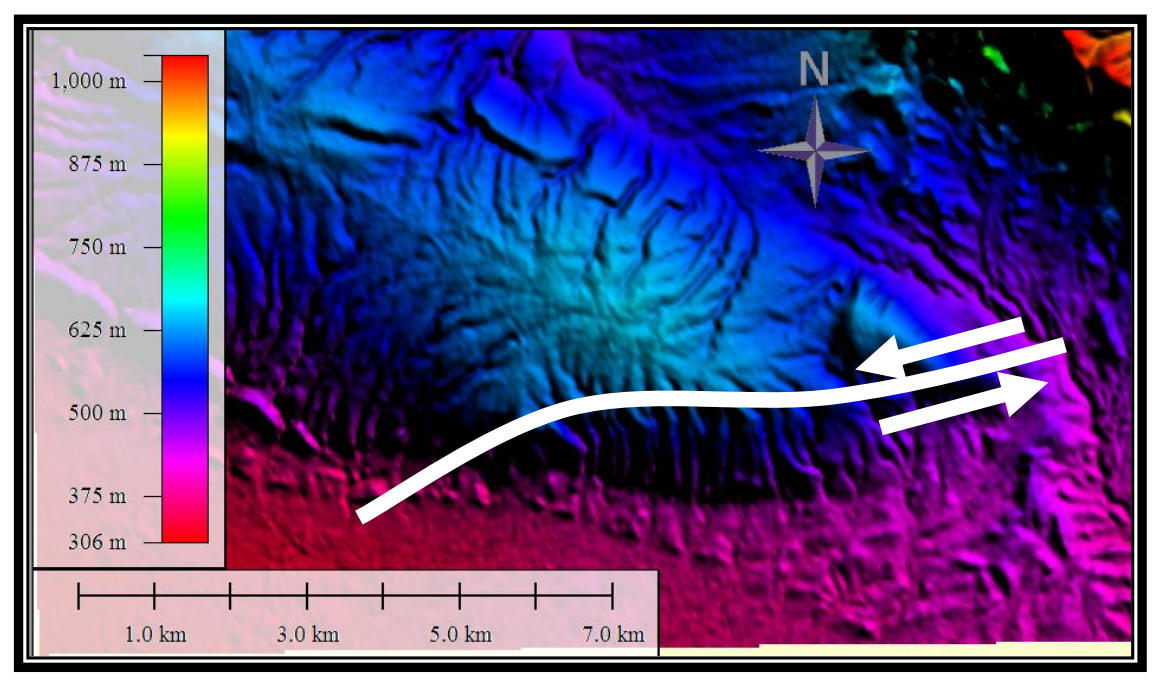

Fig.6: Digital elevation model and the fault deformation . 
Many researchers have been characterized by a linked tectonic landforms by systematically deflected drainage patterns, aligned streams, and fault scarp (Zang et al.,1995). Offset of drainage streams provides possibly the most convincing criteria for active strike-slip faulting (Zang et al., 1995) or sometime in oblique-slip faults. In the study area, the surface offset of the drainage-pattern is quite demonstrable along the fault trace (Fig. 4B,4D).

\section{CONCLUSIONS}

Most of the drainage-pattern which cut-through through the fault in the limestone rocks of Pila Spi Formation have semi-linear partitions above and beneath the fault, signifying that they originally cut straight across the fault.

Tectonic structures including systematic deflection of drainage-pattern, structural ridges offset and configuration of fault-scarp show that the study area is undergoing active tectonics. The fault at the southeastern plunge of Bashqia anticline is conformable with the regional shortening stress of the Arabian-Eurasian plate, and that would identify this fault as apparent strike-slip fault according to the fracture shear model (Fig.7).

The reverse slip movement on the fault, which has been improved by previous studies, could be associated with apparent strike-slip movement as inferred in the percent study.

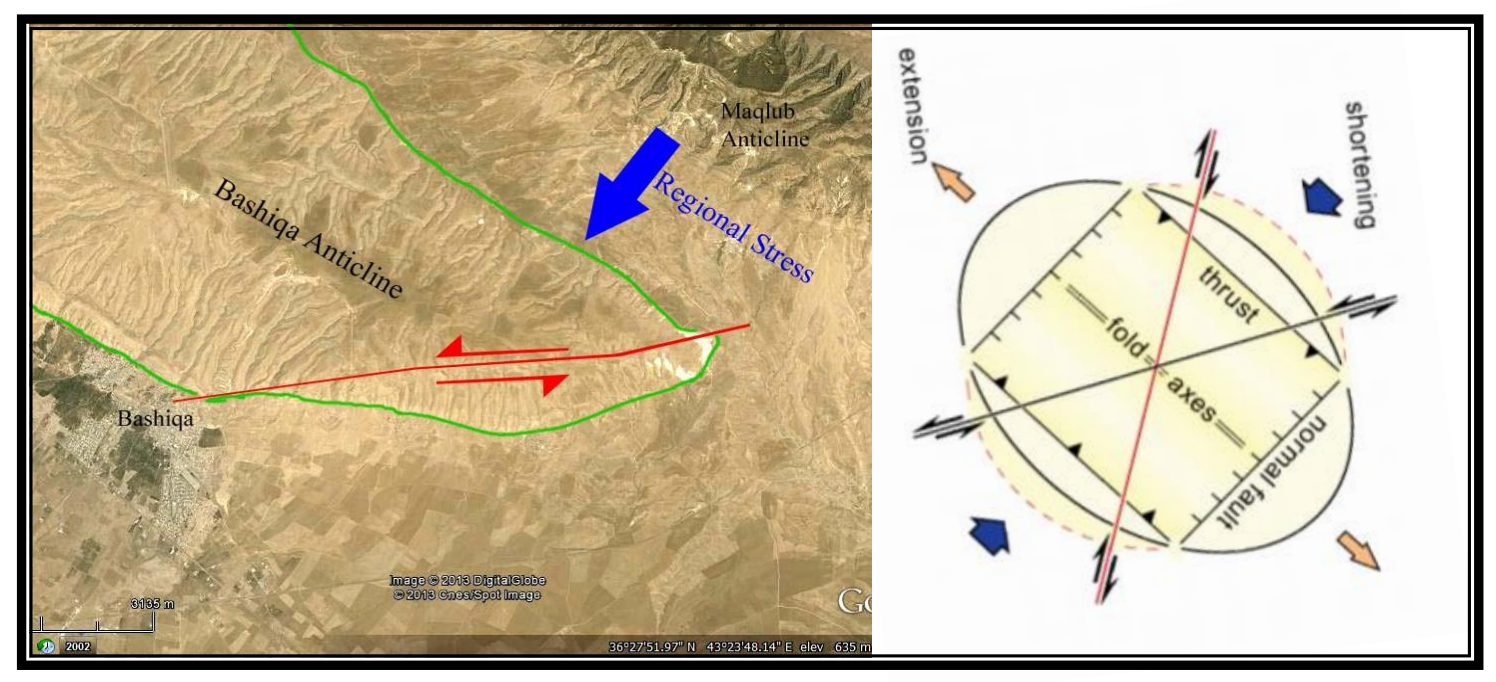

Fig.7 : Shear model to illustrate Bashqia fault relation with the regional shortening stress.

escarpment morphology in this area deforms the sedimentary rock beds and drainage pattern shape, and that has been increased due to the geometrical configuration of the fault concerning the anticline trend. All that happening in coincidence with the vertical propagation of the anticline as a response to the regional stress of shortening. 


\section{REFERENCES}

A. V. Arzhannikova, A.V.; Arzhannikov, S. G.; Jolivet, M.; Vassalo, R. and Chauvet, A.D., 2011. Morphotectonic Analysis of Pliocene-Quaternary Deformations in the Southeast of the Eastern Sayan. Geotectonics, Vol. 45, No. 2, pp. 142-156.

Al-Azzawi, A.GH., 2010. Structural and tectonic analysis of Bashiqa and Fadhilyiah anticlines - Northern Iraq. M.Sc. Thesis (unpublished), Geology Dept., College of Sciences, Mosul University.

Emami, H., 2008. Foreland propagation of folding and structure of the mountain front flexure in the pusht-e kuh arc (Zagros, Iran). Ph.D. thesis, University of Barcelona, Geology Faculty, Spain.

Geosurv, 1995. Geological map of Al-Mosul quadrangle, sheet NJ-38-13. The State Establishment of Geological Survey and Mining, Baghdad, Iraq.

Goldsworthy, M., and Jackson, J., 2000. Active normal fault evolution in Greece revealed by geomorphology and drainage pattern. J. Geol. Soc. London, Vol.157, pp.967-981.

Jassim, S. Z., and Goff, J.C., 2006. Geology of Iraq. Published by Dolin, Prague and Museum, Brno, Czech Republic, 337p.

Keller, F.A., and Pinter, N., 2002. Active Tectonics (Earthquakes, uplift, and landscape). Prentice-Hall, NJ. USA., 362p.

Khalifa A., Çakır Z., Owen L.A. and Kaya Ş., 2018. Morphotectonic analysis of the East Anatolian Fault, Turkey. Turkish Journal of Earth Sciences, Vol. 27, pp. $110-126$

Moriyama, T., and Lin, A., 2002. Active strike-slip faulting history inferred from offsets of topographic features and basement rocks: A case study of the ArimaTakasuki tectonic line, southwest Japan. Tectonophysics, Vol.344, pp.81-101.

Salih, M.R. and Al-Daghastani, H. S., 1993. Thrust mechanism and their relationship with folding and geomorphology of Bashiqa structure, North Iraq. Iraqi Geological Journal, Vol. 26, No.2, pp. 62-76.

Zang, Y. Q., Vergely, P., and Mercier, J., 1995. Active faulting in and along the Quinling Range (China) inferred from SPOT imagery analysis and extension tectonics of south China. Tectonophicys. , Vol.243, pp.69-95. 